\title{
Jewish Families in the United States
}

Trevan Hatch

Brigham Young University - Provo, trevan_hatch@byu.edu

Loren Marks

David C. Dollahite

Brigham Young University, david_dollahite@byu.edu

Follow this and additional works at: https://scholarsarchive.byu.edu/facpub

Part of the Jewish Studies Commons

\section{Original Publication Citation}

Hatch, T. G., Marks, L. D., \& Dollahite, D. C. (2017). Jewish families in the United States. In L. D. Marks \& D. C. Dollahite, Religion and families: An introduction (pp. 173-190). New York:

Routledge/Taylor \& Francis

\section{BYU ScholarsArchive Citation}

Hatch, Trevan; Marks, Loren; and Dollahite, David C., "Jewish Families in the United States" (2017). Faculty Publications. 3056.

https://scholarsarchive.byu.edu/facpub/3056

This Peer-Reviewed Article is brought to you for free and open access by BYU ScholarsArchive. It has been accepted for inclusion in Faculty Publications by an authorized administrator of BYU ScholarsArchive. For more information, please contact ellen_amatangelo@byu.edu. 


\section{Jewish Families in the United States'}

As mentioned in chapter 8 , the rich context of religious minority families offers the chance to highlight issues like identity formation in youth and emerging adults, the importance of social support from their religious community, and the unique challenges religious minorities face as they strive to live their religion. In this chapter we feature Judaism and the 30 Jewish families from the American Families of Faith project.

\section{Jewish Family Life}

The worldwide Jewish population as of 2010 was estimated by the Pew Research Center (2012) to be 13.85 million, or $0.2 \%$ of the world's population. Pew researchers also estimated that the United States contained the largest population of Jews in the world at 5.69 million (41.1\%), followed by Israel at 5.61 million (40.5\%). About $2 \%$ of Americans are Jewish. Due to a longstanding emphasis on the importance of knowledge and education, Jewish Americans are disproportionately involved in higher education and several influential fields in American society. Indeed, education is a major part of child-rearing and family life for most Jewish families.

\section{Who Is a Jew? What Is Judaism?}

Before discussing some of the features of American Jewish family life, it may be helpful to keep a broad definition of "Jews" and "Judaism" in mind while 
proceeding through this section. The term "Jew" (Yehudi in Hebrew) is derived from a biblical tribe named after Judah (Yehudah in Hebrew), who lived about 1,600 years BCE. Judah's 11 brothers also had tribes named after them. These 12 tribal families and their descendants, together, were called "Hebrews" or "Israelites" (named after Judah's father). Over a period of about 600 years, the tribe of Judah became the dominant tribe among the Israelites due to a combination of superior geographic location and greater fortune in surviving multiple invasions and deportations by neighboring nations. Thus, "Judah" eventually replaced, or was synonymous with, "Israel," and by $600 \mathrm{BCE}$, members of all 12 tribes of Israel were calling themselves "Jews."

The ancient Israelites, and later Jews, had a system of religious worship centered on their temple that involved prayer and many sacrificial and purification rituals. We call that ancient religious system "Judaism." It is the religion of the Jewish people (although contemporary Judaism is quite different in various ways from its ancient precursor, perhaps most importantly since ancient Judaism was based in worship at the Temple in Jerusalem). In other words, in the ancient world Jews were known as being an ethnic group and a religious group; therefore, one was also "Jewish" if he or she converted to the Jewish legal and religious system.

Today, as in the ancient world, one is "Jewish" either by lineage or by religion (or both). Not all Jews by lineage are adherents to the religion of Judaism, and not all religious Jews are of literal Jewish descent (e.g., converts to Judaism). Some lineal Jews, for example, may be Catholic, Protestant, or Buddhist in their religion (although many Orthodox Jews do not consider one who has adopted another religion to be Jewish). Further, Jews who are blood relatives of ancient Jews are found among many nations and ethnicities (e.g., French Jews, German Jews, Spanish Jews, etc.), while Jews by religion may be Asian, African, Hispanic, or even Persian or Arab. You can see how difficult it can be to discuss "Judaism," "Jews," or "Jewish history" because even the definitions of the terms are neither clear nor agreed upon by scholars or by all Jews themselves. In this chapter (and in our American Families of Faith project), we focus on families who practice the Jewish religion (including both Jews by lineage and a minority who are Jews by conversion).

\section{Jews in the United States and Jewish U.S. Demographics}

Just as there are various ways to be Christian (there are hundreds of Christian denominations; Prothero, 2010), Jews have developed several different ideas of what Judaism is or should be. Today, three main groups within Judaism have emerged out of the struggle to define Judaism: Conservative, Orthodox, and Reform. While there are other branches in Judaism (e.g., Reconstructionist), these three branches include the great majority of religious Jews. Reform Judaism first developed in Western Europe in the 19 th century through the rationale that many Jewish practices and beliefs were outdated, superstitious, or unnecessary. Some Jewish thinkers proposed that the Jewish community should adjust and reinterpret Judaism to be more modern and useful. Reform Judaism quickly spread across Western Europe, and by the early 1820s, a Reform Synagogue was established in Charleston, South Carolina. Reform Jews currently comprise about 35\% of the Jewish population in the United States, making it the largest Jewish group in America (Pew, 2013).

Orthodox Judaism emerged in response to Reform Judaism. Some Jews who rejected proposals for change argued that Judaism could not be reformed because it is a revealed religion (i.e., revealed by God); therefore, any attempt to reform Judaism was rejected by these more traditional, or "Orthodox," Jews. According to many Orthodox Jews, Reform Judaism is not considered authentic Judaism. Orthodox Jews constitute roughly 10\% of the Jewish population in the United States - the smallest of the three major branches in America (Pew, 2013). However, nearly 20\% of Jews that belong to a synagogue identify as Orthodox. The proportion of Jewish families that are Orthodox is currently increasing for at least two reasons: (1) Orthodox families tend to have significantly more children than Reform, Conservative, and non-religious Jewish families, and (2) there is a higher rate of intermarriage (marrying a non-Jewish spouse) among Conservative, Reform, and nonreligious Jews, and only about one-third of children in intermarried families are raised Jewish. Thus, over time, the proportion of Jewish families who are Orthodox (more strictly observant of Jewish law) will likely continue to increase.

Conservative Judaism also emerged in relation to Orthodox Judaism and Reform Judaism. The Conservative movement flourished because it attracted Jews who viewed the Orthodox movement as too antiquated or unrealistic and who saw the Reform movement as too secular and non-observant. Conservative Judaism sought to conserve traditional Jewish practices and Jewish thought, like Orthodox Jews, while adapting to the ever-changing environment around them, like Reform Jews. Approximately $18 \%$ of American Jews are associated with the Conservative movement (Pew, 2013). It is important to know the basic distinctions between these three groups when examining American Jewish family life because significant differences are manifested 
between them. "Judaism" is not a single, uniform system of practices and beliefs. There is a wide spectrum of ideas regarding how Judaism should be lived among American Jews, and this is important to keep in mind while reading this chapter.

Based on a recent Pew (2013) survey, a large majority of Jews, even secular Jews, are proud to be Jewish and are involved in Judaism by attending local Jewish events, enrolling their kids in Hebrew school or Jewish day school, sending their kids to Jewish summer camps, or participating in Jewish holiday activities and traditions. We now survey three aspects of Jewish family life that highlight ways religion impacts Jewish individuals and families.

\section{Challenges of Being a Religious Minority: Jewish Perspectives}

Much has been written on anti-Semitism and the mistreatment of Jewish persons across time and history. The details of the Holocaust and the pogroms among many possible examples of persecution of Jews, are horrific. These, however, are not our focus here. Instead, we turn our attention to challenges faced by contemporary Jewish families living in the United States. How are these families affected by their specific religious minority status in a country with an overwhelmingly Christian population (about $70 \%$ of Americans art Christian)? In our American Families of Fath data, one challenge repeatedly mentioned by Jewish mothers and fathers was that of observing Shabbat (the Sabbath) with family. Shabbat, however, was also mentioned as deeply meaningful by many families. We will discuss both the challenges and the benefits of Shabbat in this chapter.

The following three quotes, from three different Jewish families, illustrate some of the challenges of observing Shabbat in the home as a religious minority.

Ruth (Reform convert): The fact that we're not going on a weekly basis to services is something I'm trying to deal with, because it has a lot of implications. Friday nights are very hard. Saturday mornings aren't all that much easier, and the Rabbi has started a Saturday morning Sabbath service, to accommodate [some] families. . . . You know, the Friday nights are just impossible, with kids and their activities. But this concert was on the Sabbath, it was Friday night, and so we haven't made a rule in our family, we haven't said, "No outside activities on Fridays." And I don't know if we need to make that rule, and that's going to be a challenge for us, I think, to deal with. Because, if it's not Saturday night, if you say, "Okay, well fine, no Saturday morning," . . . then does that mean that they can't do soccer? Well yeah, it means they can't do soccer. So, what do you give up?

Rebecca (Reform mother): [Observing Sabbath] on a more regular basis is hard because the Friday nights, getting the kids there, there's football games and parties, and stuff they get invited to. We've tried to say, "Okay, if you don't go to synagogue on Friday night, then we're going to go on Saturday morning instead. This is what we do." We're going to give the kids that choice, if we don't go on Friday night, we go on Saturday morning. Well, [my husband's] a doctor, he's on-call many nights, we have Sunday school on Sunday morning, so Saturday morning is our only [free] day of the week ... and most of the time, there's a baseball game or other kid's sports stuff on Saturday. Because we live in the world we live in, it's hard for us to really live Jewish as much as we would like to. We have to fight the calendar.

Melanie (Conservative mother): We had a big crisis that we had to confront, and that was whether or not we would let the kids play soccer on Shabbat, on Saturday morning.

Joshua (Conservative husband): Yeah, because all of [our daughter's] friends were playing soccer, so we let her do it for a few weekends, and we hated it, because it just stole the family away from us. And in the end we decided: No, we weren't going to do it ever again. And we've really held to that, not just with the children, but with ourselves as well. With very few exceptions, very rare exceptions. [Shabbat]'s the one time we're all together.

These interview excerpts - from Reform and Conservative familiescapture the struggles faced when children's secular activities collide with the synagogue and Shabbat schedule. In these three families, we see slightly different perspectives on and responses to the constant cultural conflicts associated with Sabbath observance. Typically, Modern Orthodox families are more "strict" in their observance of Shabbat, and most would chose not to have their children involved in secular/sports activities on Friday evening or Saturday until after sundown. We now move from the challenge of conflicts associated with Shabbat to the topic of the religious community within Judaism. 


\section{Religious Community}

Research shows that social support from a religious community provides families, including religious minority families, with many physical health, mental health, and relational health benefits (Koenig, King, \& Carson, 2012; Koenig, McCullough, \& Larson, 2001; Marks, 2005, 2006). For example, parents who scored higher on measures of religious involvement and perceived social support from their religious community reported more favorable parenting practices and lower hostility toward others, including their children (Strayhorn, Weidman, \& Larson, 1990; Wilcox, 1998).

According to a study of 200 participants in 20 U.S. religions, social support from a religious community was a stronger predictor of family relationship satisfaction than was a religious belief in divine intervention (Abbott, Berry, \& Meredith, 1990). One recent study that moved beyond the variable of frequency of religious attendance (Olson, Goddard, \& Marshall, 2013) used a random sample of 1,204 young married participants and discovered that attendance at worship services was not positively associated with marital commitment. Rather, perceived support from one's religious community was positively related to marital commitment. In other words, it may be the case that strong social support from one's religious community is more important for marital and family relationship satisfaction than simply attending religious services, per se. To frame this differently, it is not just having a synagogue mosque, or church to attend that seems to strengthen marriage; it appear to be the social, familial, and marital support received from friends in the faith community that matters more. Olson and colleagues' research suggest: how significant a strong social support group may be for enhancing marriage and family relationships. With this research in mind, we will consider som aspects of American Jewish families, using additional data from the Americar Families of Faith project that highlight the importance of support from the local religious community, especially for religious minorities.

Unlike Jews in most parts of the United States, Christians likely have a support structure at school and work, where many (if not most) of theit classmates and co-workers are at least nominal Christians. Their religious symbols and holidays are supported by the media and by advertisers through TV shows, commercials, concerts, light displays, and so forth. Jews, on the other hand, are typically more limited in religious social support from the surrounding community, which primarily comes through the synagogue or local Jewish Community Center (if they have one in their community, and many do not). In this context, consider the comment from a Reform Jewish man from a mid-sized southern city:
Jerry: [Our congregation] is really supportive and it helps us continue traditions where we might have a conflict between our various roles in the secular world and the religious world. Having a congregation to rely on helps us, and in many ways, enables us to do both things very well. It also creates a community where the kids feel like they belong to a group of people. We have very close friends from the synagogue who we engage with outside of the synagogue all the time. Our kids know that they're not the only Jews in [this city].

An Orthodox couple, William and Sheri, also explained that the local Jewish community is important to them because it functions as their extended family:

William: The synagogue is like an extended family. It's [a] nice place to go. Our daughter, most of her friends are at synagogue and she likes to go. Our son, most of his friends are not at synagogue and he does not like to go ... so there's a social aspect.

Sheri: Observance is important to me but the sense of community and continuity is [also] great ... the extended Jewish community has become our family. Because our families are spread out across the country, they [our friends from the synagogue] are our family.

A Jewish woman from California, Rebecca, explained what the support from her local Jewish community means to her and her family:

Our synagogue is almost like a dysfunctional family. Most of the people in our synagogue are people whose paths we would never cross anywhere else. We run in different social circles, we are on different career paths, different aged kids, different schools. But, what we have in common with these people is what we share in the four walls of that building, and in thousands of years of Jewish tradition, and I can't explain why it clicks here better than anyplace else we've ever lived. . . . It is such a community.

Rebecca went on to share the following narrative that illustrated this sense of community:

We had a real tragedy a few years ago in our synagogue where a family who w[ere] not even member[s] of [my particular] synagogue, but a Jewish family in town lost a child, and it was a horrific situation. People 
just showed up, came from out of the woodwork. It was a very pain. ful situation to walk into. You feel like you are invading somebodys privacy, to go into their home at such a painful time when you don' even know these people. Yet they needed a Jewish community to help them pray and do what Jews do at this time, and people just showed up. . . . They brought food. They came night after night, bigger num bers every night. People just were there . . . because this is what Jews do for other Jews.

(Hatch, 2015

Comments from these Jewish parents illustrate why their community is so important to them and their families. They have access to a support group that understands their sensibilities, traditions, and struggles as Jews. In addition to general support from the community, research shows that shared experiences are also a crucial part of belonging to a community. Shared religious experiences are beneficial because they create common interests for couples, families, and the religious community.

Perhaps the best illustration of a shared cultural and religious community experience that impacts the family in a Jewish context is the tradition of bar/ bat mitzvah. According to the latest Pew (2013) research on American Jews, nearly $60 \%$ of religiously involved Jews and nearly $30 \%$ of secular Jews had a $\mathrm{bar} / \mathrm{bat}$ mitzvah ceremony.

The term bar/bat mitzvah means "son/daughter of the commandment" and also refers to a series of Jewish rituals performed by adolescent males and females at ages 13 and 12, respectively, at their bar/bat mitzvah celebration (typically held at a synagogue). The millennia-old tradition of becoming bar/bat mitzvah consists of leading part of the worship service at the synagogue and reading the sacred texts in Hebrew in front of the assembly. These rituals signify that the community hereafter recognizes the adolescent as an adult. Many parents plan months in advance by hiring a teacher to get their child ready for the big day. For some families, the bar/bat mitzvah is similar to a high school graduation where photographers are hired to capture the event, invitations are issued to friends and family, and the adolescent receives gifts and monetary donations.

This rite of passage is typically a special event for the nuclear and extended family and the local Jewish community (Hatch \& Marks, 2014). Although technically the bar/bat mitzvah ceremony is an achievement of the individual, the family and many from the community are often involved in the preparation of the event, as well as in the ceremony itself. The following comment from a Reform Jewish couple illustrates the importance of the shared religious experience that bar/bat mitzvah provides:

Susannah (wife): When my daughter had her bat mitzvah three years ago, this was something she wanted to do. So, when it came time for my son, I said, "You know, this is strictly your decision. You're doing the work. You've got to want to do this." And he said, "Yes, my religion is important to me." So, he did it. That's one thing I think we've given our children is a strong Jewish belief and they feel a part of the congregation.

Matthias (husband): The services, the bar and bat mitzvahs, those take a long commitment, a couple of years of study, weekly classes, things like that. And, it brought our children together, my daughter having done it before, helped my son learn the Hebrew, and things like that. It may be, to some extent, those events and the stuff associated with them ... brought family into town, which is not something that happens [otherwise]. Our families don't get together that much, [but] that contributed to it.

To summarize our very brief discussion of Jewish families in a faith community context, we see that a synagogue can serve as an "extended family." This can be particularly important for Jewish families living in areas with a smaller Jewish population. Further, synagogue-based rituals including bar/ bat mitzvah seem to unite biological and extended families for these life course events. As a result, the synagogue seems to have the power to both create a functional "extended family" for Jewish families as well as to unite and reunite literal extended family. Even so, as important as the synagogue and synagogue-based rituals and events (like bar/bat mitzvah celebrations) are for many Jewish families, the center of Judaism for many others is not the synagogue but the home, as discussed next.

\section{Jewish Religious Observance in the Home}

Cohen and Eisen (2000) in their classic book, The Jew Within, suggested that younger generations of Jews increasingly seem to be honoring their heritage and observing their religion in the home, with family. Jewish young adults, similar to young adults in general (Smith \& Snell, 2009), appear to be moving away from the "organizations, institutions, and causes that used to anchor identity and shape behavior" for previous generations (Cohen 8 Eisen, 2000, p. 2). 
Goldscheider (2004) similarly acknowledged that Jews generally appear t have become "less attached to religious activities and institutions" (p. 100) In many cases, however, the family seems to be filling some of the vacuum Goldscheider (2004) argued that Judaism is not in decline, like many hav suggested, but that Judaism is in transition or transformation. This transfor. mation has consisted of a movement away from communal institutions and toward the family.

Cohen (1999) also posited that Jewish identity has undertaken salien transformations. He explained how Jewish cultural identities have transi tioned through the 19th and 20th centuries from collective-based identity tc individual-based identity (Cohen, 1999; Cohen \& Eisen, 2000). Jews in North America, he argued, now feel free to incorporate into their individual and family lives only those aspects of Jewish culture and religion that are personally meaningful - and the retained aspects tend to be those more relevant to the family and the home (Cohen 8 Eisen, 2000). The following comments from American Families of Faith participants further illustrate what Cohen, Eisen, and Goldscheider have articulated about the significance of the transformation of American Judaism from the institution and synagogue to wha some refer to as "home-based Judaism," where families live their religion ir the home in ways that are meaningful to them.

Yigal (Orthodox father of two): There are so many reasons why we love our [family traditions]. Number one, we love it because we made it up and we both feel that Judaism . . . well, we don't believe that there was a tradition that was handed down in this kind of linear ironclad way and that if you are part of the tradition you do wha you are told and do exactly the things that the generation befort you did. No! We believe that Judaism is a very fluid and dynami thing that is constantly changing and has changed with different pressure[s] throughout history and that we have the power today to do with it as we will. Obviously it's based on certain princi. ples and inspirations that we didn't just make up ourselves, bu still we take it in directions that [we] decide to take it. But I alsc think [about] what are the beautiful characteristics of Judaism and what are the things that I would want to have in my Juda ism? Much more than a rigid observance of practices or doctrines there would be a sense of love in the family - that the parent love and respect each other, and that parents love and respect th children, and the children love the parents, and that their Judaism is an expression of that.
Yigal went on to say:

Sometimes you have parents that say, "This is what Judaism means, [so] you must do X." Even if the kids hate it, [the parents say], "To Hell with you, you must do it!" and that is the kind of Judaism that I grew up with. I disagree with the kind of Judaism where I just had to do certain things even if it made me miserable, you know-that we needed to do it because that is what you are "supposed to do." And that kind of slavish obedience to tradition is anathema to me. I loathe it! So because of that, the things that I loathe, I do the opposite. The things that are beautiful that the children and parents love and that we enjoy, we do it zven if we aren't commanded to do, or even if we are commanded to to it. It injects our Judaism and our family with a sense of joy with the traditions, rather than the sense of obligation to follow traditions.

Earlier in our interview with his family, Yigal commented that he and his wife, Alissa, disagreed with a passage in the liturgy, and so they decided to not say it during the synagogue services. They essentially omitted it from their form of Judaism. Like Yigal's family, many religious people take what they believe they need (or want), based on their life's experiences, and discard what they do not find as helpful. Notice that Yigal referred to his religion as "my Judaism" and "our Judaism" several times. For his family, Judaism is special (in part) because it can be adapted. Indeed, for most contemporary Jews, "Judaism" presupposes change, adaptation, and even contradiction. However, Orthodox Judaism is less prone to value change and instead emphasizes adherence to tradition and more strict observance of Jewish law. This adaptive approach that most Jews bring to their observance of Judaism in the 21st century, as articulated by Yigal, reflects what sociologists like Cohen, Eisen, and Goldscheider have found in their research.

As previously mentioned, not all Jews appreciate or embrace flexible parameters of living their Judaism. Rabbi Jeffrey Salkin, for example, warned that observing only those aspects of one's religion that are meaningful at the time, or simply "following your bliss," is the "antithesis of living in covenant" (Kaplan, 2009, p. 60). Another American Jewish rabbi, Dana Kaplan, argued (2009) that the "New Supermarket Judaism" practiced by many Jews impedes experiencing religion the way "it was intended to be experienced." Rabbi Kaplan has explained:

The plethora of choice is intoxicating, but ultimately unsatisfying. Approaching religion as one would a salad bar is unlikely to provide the 
person with the personal discipline necessary to experience religiosity as it was intended to be experienced. There is an intense spiritual satisfaction that is the result of self-sacrifice, and the perpetual "religious tourist" is unlikely to feel that sense of satisfaction since they have never made a commitment to sacrifice. Rather, they are constantly looking and evaluating and making temporary choices, only to reverse themselves and consider yet other options.

Despite the pushback from some Jewish leaders and authors against those practicing a "cafeteria religion," it is likely that most American Jews, similar to people in other religions, will continue to approach Judaism in this "I'll take what I want" manner.

We now return our focus specifically to Jewish practice in a family context. Consider the three following AFF quotes from Reform, Conservative, and Orthodox Jewish families on the significance of the home in living as a Jew. A Reform convert confided:

Ruth: I feel I'm right now a little conflicted about the fact that we don' go to Friday night services. I know I have mentioned it several times in this interview. Because I'm hearing from the Rabbi that he really wants us to come more, and coming from a Catholic background, where you always went to church on Sunday, I mean that was not an optional thing. But in the Jewish community, the at-home participation in the Sabbath is equivalent to, not the same as going to synagogue, but that's the more important thing. If you had to only do one, you should light candles and say prayers at home.

A Conservative couple explained:

Interviewer: Is your religious life centered in your home and family or your synagogue?

Daniel: $\quad$ Home.

Wendy: Home. Home and family. The synagogue is an appendage. . I believe if there wasn't a synagogue... if, God forbid, ther [was] like a Holocaust or something where we were forced to hide and practice Judaism, I would still figure out a way to get: done in the home.

Daniel: Well, in fact, you don't need a rabbi in Judaism for the religion 1 [continue] . . . In fact, so many times in the pogroms, they sta with the rabbis-they kill the rabbis first. . . A And you know what? It still hasn't worked. And the reason is because it's kind of like the Second Amendment in the U.S. The reason that the U.S. will never be taken over is because every family has a gun. And so it's like every Jew, the religion or the culture of Judaism or the essence, the nugget of Judaism resides within every Jew in the home by and large, so it's very hard to extinguish that. The home is really ... the center of the universe for us, for this particular Jewish family. We really enjoy [and] relish life in the synagogue, but if the synagogue went away, if we went into hiding, if we went into hibernation, if we had to disperse, we would be able to persevere [Judaism].

An Orthodox couple, when asked where their religious life was centered, responded:

ibram: I would say that, and I can only give this to you in a percentage, I would say that our religious life is centered in the home probably something like $60 \%$ [home and] $40 \%$ [synagogue] or $70 \%-30 \%$.

Naomi: I think my percentage would be different, though. I think it would be more like $90 \%$ home. If you think about it, every major-with the exception of the High Holy Days-every major mitzvah [commandment] or every major holiday is done in the home. Fasts are at home. Pesach [Passover] is at home. Sukkot is at home. Shavuot is at home. All of these are family-based holidays. Yeah, lots of times you have guests or you are a guest among families in the community, but ... you go to [synagogue], but when you're done with [synagogue], the celebration is at home.

Consistent with Naomi's report, many of the salient Jewish traditions practiced in the home are associated with the Sabbath and major holidays, like Passover. According to the Pew survey (2013), nearly half of Jews (45\%) who have a Jewish spouse reported that they always or usually light Shabbat candles on Friday evenings. However, that percentage would likely be higher if the survey included additional Sabbath traditions in the home, such as special family meals.

Jewish participants in the American Families of Faith project mentioned practices associated with the Sabbath more than any other cultural or religious practice. Of the 30 Jewish families in the AFF sample, 28 (93\%) discussed the Sabbath during the interview, and most mentioned it multiple times. More 
specifically, when asked, "What practices or observances hold special meaning for you as a couple or family?" 19 families (63\%) immediately mentioned the Shab. bat. The three main themes that emerged from the AFF project regarding the Sabbath were: 1) Sabbath traditions help form and maintain strong Jewish identity; 2) Sabbath facilitates peace and relaxation; and 3) Sabbath traditions unify the family (Hatch, 2015; Marks, Hatch, \& Dollahite, under review). The following seven comments from Jewish mothers illustrate the dynamics for many families of observing Shabbat at home:

Wendy (Conservative): The kids know Friday night is Shabbat. They don't make plans. They know it's Shabbat. I'll pick them up from school [and] they'll be like "Tonight's Shabbat. Who's coming?" They're always asking. The older one said to me the other night, "I love Shabbat." .. . Everybody's together and we'll set the table and it's a nicer dinner. ... We'll set the table, the kids, depending on who's coming, we'll put on nicer clothes, but we do the lights and the cooking.

Kristen (Reform): When our kids were younger we did Shabbat dinners every Friday night and it was really fun for all of us. . . My daughter would run upstairs and put on her special Shabbat clothes and she and I would make challah (traditional Sabbath bread) together.

Melanie (Conservative): It's funny, there's all this stressful air before Shabbat, getting ready and all this, and then you light the candles. Everything does change. And you know the laws about Shabbat, you're not even supposed to be thinking anything stressful, let alone talking about anything stressful. It's like you leave all the stresses of the rest $o$ : the week behind ... and the kids are always very excited about it. They know that no one's going anywhere, no one's answering the phone, no one's driving anywhere, that we're just going to be here as a family. ... It's fun. We always change our clothes and put on nict clothes. .. . It's our moment. It's our evening and time to kind of .. become a unit once again. We've all scattered and gone our separat ways during the week.

Esther (Orthodox): The special thing about Shabbat [is that] we always eat supper together, so at our house it's not so unique that we're al' around the table. But I try to make special things for Shabbat that know that the kids really like and they're looking forward to it.

Rachel (non-Orthodox but unspecified): Friday nights are big nights for us. [In the past], we took them to services every Friday night. We haven't really gone for the last year, but every Friday night, we [do] get out the Sabbath candles, and I light the candles, and say the prayer in
Hebrew, and I've got wine glasses, so we do grape juice in the wine glasses for the kids, and the boys know the prayer over the wine, and then they all do the prayer over the bread. . . . They know that Friday night is the Sabbath, and so that's our big deal ... The kids love that. They love lighting the candles, and saying the prayers. They like drinking out of wine glasses. They think that's a big deal.

Simcha (Orthodox): [Shabbat] just makes us stop and rest. Normally during the week [we're] running around, whether it's work or errands or shopping. ... This quiets us down. This gives us a rest. I mean we can't do anything. You can't go anywhere. I can't talk on the phone, it's not ringing. The TV is not on. It just, you know, you rest. You take naps, I go to classes. We just, we see friends, we talk. You know, we play, as a family we play games. Things like that.

lebbie (Conservative): [Shabbat gives us] a chance to breathe, to relax. We've had a busy week and here's our time to be together and we always take a deep breath before we do this and let all the thoughts, craziness and worries, and everything slip away. . . I think that when we take the time out, when we light the candles Friday night, that's a time that I feel really close to them ... When we sit across the table from each other, my husband and I, and the candles are lit, and you see the kids, there is something you get from that that is so deep. It's just a feeling that all is right in the world ... it doesn't matter what else is going on. Right in that circle ... it's awe-inspiring.

These mothers help convey, in richness and color, the active power associated with home-based Jewish practices for them, their husbands, and their children. These descriptions convey a family-unifying ideal. Our research demonstrates that the family ritual of Shabbat is a uniquely important (even central) element of what Judaism means to many observant families.

\section{Conclusion}

In this chapter we have shown, through the eyes of observant Jewish families, which aspects of Judaism seem to be most salient for families. We also caught a brief glimpse of the challenges and frustrations Jews experience as members of a minority religion in the United States. For example, several families reported that they felt forced to choose between: (a) observing the Sabbath (e.g., staying home with family and attending Sabbath synagogue services on Friday nights and Saturday mornings) or (b) being active in their non-Jewish 
community by participating in school dances, school plays, sporting events, work parties, and other community events that are usually scheduled on Friday nights and Saturdays.

We also learned in the chapter, as a natural transition from the section on "challenges," that the local Jewish community and synagogue are often very important for providing a strong social support structure. Members of the community enjoy a sense of belonging (Marks, Dollahite, \& Barker, 2012). Their fellow adherents and like-minded friends reportedly serve as an "extended family." Many Jews in the United States do not live within driving distance from their parents, siblings, and extended family; therefore, their local Jewish community becomes their family and their social support group.

The final aspect of American Jewish families that we considered in this chapter deals with religious observance in the home. Although the religious community and synagogue serve a meaningful purpose and seem to foster a sense of identity and belonging, many Jews identify "home-based Judaism" as being more salient and meaningful for living as a Jew than "synagogue-based Judaism." Shabbat (Sabbath) is the most common Jewish observance in the home, and most Jews, even many non-observant Jews, observe some aspects of the Sabbath with family and friends. Sabbath activities may include family time, nice dinners, special food (e.g., challah), special clothing, dancing, music, and lighting candles. "Tradition," the word that brings to mind the classic film Fiddler on the Roof, is salient for many Jews, and Sabbath activities are often a vitally important vehicle to help Jewish families remember their traditions and disseminate them to the next generation.

\section{Chapter Summary Points}

1. Being a "Jew" can refer to either being of Israelite descent or a member of the Jewish faith.

2. There are three main groups within Judaism: Orthodox, Conservative and Reform.

3. Observing Shabbat in the United States can be a challenge, given perer nial conflicts with cultural, school, and business-related events.

4. The bar/bat mitzvah is an example of a sacred tradition that is a shared experience with the Jewish religious community.

5. Scholars note some trends that indicate a decline in synagogue-based Judaism, whereas other scholars explain this trend as a "transition or transformation" to more home-based observance.
6. While the current trend in Judaism appears to be moving away from institutional religion, some scholars contend that it is mirrored by a reactionary trend turning toward more home, family, and individually-based worship.

7. Shabbat is considered an important ritual by many Jewish families because of its identity-maintaining, peace-promoting, and family-unifying nature.

\section{Review Questions}

1. According to the text, what are some differences between the Reform, Orthodox, and Conservative branches of Judaism?

2. What are some benefits for families related to religious communities that are highlighted in the text?

3. What does the term bar/bat mitzvah mean? How does this translation of the term relate to the ritual of a bar/bat mitzvah?

4. What conclusions have Cohen and Eisen (2000) come to in their book?

5. What religious practice was discussed by $93 \%$ of Jewish participants in the AFF project? What themes have emerged from Jewish discussion of this ritual?

\section{Note}

1. This chapter is authored with Trevan Hatch.

\section{References}

Abbott, D. A., Berry, M., \& Meredith, W. H. (1990). Religious belief and practice: A potential asset for helping families. Family Relations, 39, 443-448.

Cohen, S. M. (1999). Introduction. In S. M. Cohen, \& G. Horencyzk (Eds.), National variations in Jewish identity: Implications for Jewish education (pp. 1-17). Albany, NY: State University of New York Press.

Cohen, S. M., \& Eisen, A. M. (2000). The Jew within: Self, family, and community in America. Bloomington, IN: Indiana University Press.

Goldscheider, C. (2004). Studying the Jewish future. Seattle, WA: University of Washington Press.

Hatch, T. (2015). Mishpacha in the American Diaspora: An Exploratory Study of Highly Involved Jewish Families. Doctoral dissertation. Louisiana State University, Baton Rouge Louisiana.

Hatch; T., \& Marks, L. (2014). Bar mitzvahs and bat mitzvahs. In L. Ganong, M. Coleman, \& J. G. Golson (Eds.), The social history of the American family (pp. 104-105). Thousand Oaks, CA: Sage. 
Kaplan, D. E. (2009). Contemporary American Judaism: Transformation and renewal. New York: Columbia University Press.

Koenig, H. G., King, D. E., \& Carson, V. B. (2012). Handbook of religion and health (2nd ed.). New York: Oxford University Press.

Koenig, H. G., McCullough, M., \& Larson, D. B. (2001). Handbook of religion and health: A century of research reviewed. New York: Oxford University Press.

Marks, L. D. (2005). Religion and bio-psycho-social health: A review and conceptual model Journal of Religion and Health, 44, 173-186.

Marks, L. D. (2006). Religion and family relational health: An overview and conceptual model. Journal of Religion and Health, 45, 603-618.

Marks, L. D., Dollahite, D. C., \& Barker, K. (2012). Don't forget home: The importance of sacred ritual in families. In J. Hoffman (Ed.), Understanding religious rituals (pp. 186-203). New York: Routledge.

Marks, L. D., Hatch, T. G., \& Dollahite, D. C. (under review). Sacred practices and family processes in a Jewish context: Shabbat as the weekly family ritual par excellence. Family Process.

Olson, J. R., Goddard, H. W., \& Marshall, J. P. (2013). Relations among risk, religiosity, and marital commitment. Journal of Couple \& Relationship Therapy, 12, 235-254.

Pew (2012). "Nones" on the rise: One-in-five adults have no religious affiliation. Pew Research Center. Retrieved from http://www.pewforum,org/uploadedFiles/Topics/ Religious_Affiliation/Unaffiliated/NonesOnTheRise-full.pdf.

Pew (October 1, 2013). A portrait of Jewish Americans. Pew Research Center. Retrieved from http://www.pewforum.org/2013/10/01/jewish-american-beliefs-attitudes-culturesurvey/.

Prothero, S. (2010). God is not one. New York: HarperOne.

Smith, C., Snell, P. (2009). Souls in transition: The religious and spiritual lives of emerging adults. New York: Oxford University Press.

Strayhorn, J. M., Weidman, C. S., \& Larson, D. (1990). A measure of religiousness, and its relation to parent and child mental health variables. Journal of Community Psychology, $18,34-43$.

Wilcox, W. B. (1998). Conservative Protestant childrearing: Authoritarian or authoritative? American Sociological Review, 63, 796-809. 